\title{
STRATEGI PENINGKATAN KINERJA KARYAWAN TAMAN BUAH MEKARSARI
}

STRATEGY FOR IMPROVING EMPLOYEE PERFORMANCE AT MEKARSARI FRUIT GARDEN

\author{
Rika Kusumawati*1, $^{*}$ M. Syamsul Maarif ${ }^{*}$, dan Sri Nurdiati*) \\ *) Sekolah Bisnis, Institut Pertanian Bogor \\ Jl. Raya Pajajaran, Bogor 16151 \\ **) Departemen Matematika Fakultas Matematika dan Ilmu Pengetahuan Alam, Institut Pertanian Bogor \\ Jl. Meranti, Kampus IPB Darmaga Bogor 16114
}

\begin{abstract}
Human resources are the main element of the organization. The organization goals will be achieved when ITS employees have high performance. The purposeS of this study were to analyze the effect of competency on employee motivation, the effect of competency on employee performance, and the effect of motivation on employee performance, and to formulate strategies for improving the employee performance at Mekarsari Fruit Garden. The respondents in this study were 167 employees selected with sampling technique using stratified random sampling. Analysis of the data used in this research included descriptive analysis of respondents, Spearman correlation test methods, analysis Structural Equation Modeling (SEM) with LISREL 8.51 and Analytical Hierarchy Process (AHP) with expert choice 2000. The results showed that 1) Competency had an effect on employee motivation at Mekarsari Fruit Garden; 2) Competency had an effect on employee performance at Mekarsari Fruit Garden; 3) Motivation had an effect on employee performance at Mekarsari Fruit Garden. The first strategy to improve employee performance was improving the prosperity of employees, and the highest factor in increasing employee performance was competency. The most influential actor was the President Director of Mekarsari Fruit Garden whereas the highest score of the objective was increasing the profit of Mekarsari Fruit Garden.
\end{abstract}

Keywords: performance, competency, motivation, strategies, Mekarsari Fruit Garden

\begin{abstract}
Abstrak: Sumber Daya Manusia (SDM) merupakan elemen utama organisasi. Tujuan organisasi akan tercapai bila pegawai di dalamnya memiliki kinerja yang tinggi. Tujuan penelitian ini adalah untuk mengalisis pengaruh kompetensi terhadap motivasi karyawan, kompetensi terhadap kinerja karyawan dan motivasi terhadap kinerja karyawan serta merumuskan strategi dalam rangka peningkatan kinerja karyawan Taman Buah Mekarsari. Responden dalam penelitian ini sebanyak 167 karyawan dengan teknik penarikan contoh menggunakan Stratified Random Sampling. Analisis data yang digunakan dalam penelitian ini meliputi analisis deskriptif responden, uji korelasi dengan metode Spearman, analisis Structural Equation Modeling (SEM) dengan LISREL 8.5, dan analytical hierarchy process (AHP) menggunakan expert choice 2000. Hasil penelitian menunjukkan bahwa: 1) Kompetensi berpengaruh terhadap motivasi karyawan Taman Buah Mekarsari; 2) Kompetensi berpengaruh terhadap kinerja karyawan Taman Buah Mekarsari; 3) Motivasi berpengaruh terhadap kinerja karyawan Taman Buah Mekarsari. Strategi pertama untuk meningkatkan kinerja karyawan adalah meningkatkan kesejahteraan karyawaan, sementara faktor tertinggi dalam hal peningkatan kinerja adalah kompetensi. Aktor yang paling berpengaruh dalam peningkatan kinerja karyawan adalah Direktur Utama, sementara skor tertinggi dari tujuan adalah meningkatkan laba Taman Buah Mekarsari.
\end{abstract}

Kata kunci: kinerja, kompetensi, motivasi, strategi, taman buah mekarsari

\footnotetext{
${ }^{1}$ Corresponding author:

Email: kusumawatirika35@gmail.com
} 


\section{PENDAHULUAN}

Agrowisata tidak dapat dipisahkan dari kegiatan rekreasi oleh karena itu sebuah tempat wisata agro haruslah memiliki paket lengkap, yaitu menarik, menghibur dan menunjang kebutuhan wisatawan dalam berbagai aspek, mulai dari sisi hiburan, edukasi, kuliner, kenyamanan berwisata dan fasilitas penunjang lainnya. Sebuah agrowisata yang memiliki paket lengkap tersebut tidak terlepas dari peran serta Sumber Daya Manusia yang berada di dalamnya. Sumber Daya Manusia (SDM) merupakan elemen utama organisasi dibandingkan elemen lain seperti modal, teknologi dan uang, sebab manusia yang mengendalikan sumber daya yang lain. Oleh karena itu, pengelolaan SDM dalam organisasi menjadi satu hal yang penting (Hariandja dan Marihot, 2002). SDM merupakan sumber dari kekuatan yang berasal dari manusia-manusia yang dapat didayagunakan oleh organisasi (Sutrisno, 2009). SDM berfokus pada kekuatan yang bersumber pada dasar bagi sebuah organisasi dalam melakukan kegiatannya dalam mencapai tujuan (Sunyoto, 2015). Oleh karena itu, sebuah tempat agrowisata haruslah memiliki SDM yang baik, SDM yang baik dapat terlihat dari kinerja yang diberikan kepada perusahaan. Terdapat tiga faktor utama yang memengaruhi individu dalam bekerja dan meningkatkan kinerjanya, yaitu kemampuan individu meningkat, ada dorongan atau usaha dari individu dan adanya dukungan dari organisasi (Mathis dan Jackson, 2003).

Kinerja karyawan adalah hasil kerja secara kualitas dan kuantitas yang dicapai seseorang karyawan dalam melaksanan tugas sesuai dengan tanggung jawab yang diberikan (Mangkunegara, 2005). Kinerja pegawai akan lebih memberikan penekanan pada dua dua faktor utama: (a) keinginan atau motivasi dari pegawai untuk bekerja yang kemudian akan menghasilkan usaha-usaha pegawai tersebut, (b) kemampuan dari pegawai untuk bekerja. Hal tersebut dapat dirumuskan dalam bentuk persamaan, yaitu $\mathrm{P}=(\mathrm{m} \mathrm{x}$ a). Maksud dari persamaan ini adalah $\mathrm{P}=$ performance (kinerja), $\mathrm{M}=$ motivation (motivasi), dan $\mathrm{a}=$ ability (kemampuan) (Sulistiyani, 2003). Kompetensi merupakan karakter, sikap atau kemampuan individual yang relatif bersifat stabil ketika menghadapi suatu situasi di tempat kerja yang terbentuk dari sinergi antara watak, konsep diri, motivasi internal serta kapasitas pengetahuan konstektual (Spencer dan Spencer, 1993). Kompetensi dikaitkan dengan satu kemampuan untuk keberhasilan dan efisiensi dalam melakukan aktivitas kerja, dan peningkatan pengetahuan, kemampuan dan keterampilan akan menghasilkan suatu kinerja yang tinggi (Hendriani et al. 2014). Sedangkan motivasi merupakan keinginan untuk menggunakan tenaga tingkat tinggi dari usahanya untuk mencapai tujuan organisasi, yang dikondisikan dengan kemampuan memuaskan beberapa tujuan individu (Robbins dan Judge, 2011).

Salah satu Agrowisata di Indonesia, yaitu Taman Buah Mekarsari (TBM) yang pengelolaannya di bawah manajemen PT. Mekar Unggul Sari merupakan kebun buah milik Yayasan Purna Bakti Pertiwi. TBM mulai beroperasi pada tanggal 1 Januari 1995, sedangkan peresmiannya dilaksanakan pada tanggal 14 Oktober 1995 bertepatan dengan Hari Pangan Sedunia ke-16. Taman Buah Mekarsari merupakan salah satu pusat pelestarian keanekaragaman hayati buah-buahan tropika terbesar di dunia, khususnya jenis buah-buahan unggul yang dikumpulkan dari seluruh daerah di Indonesia, sekaligus merupakan budidaya (agronomi), pemuliaan (breeding) dan perbanyakan bibit unggul untuk kemudian disebarluaskan kepada petani dan masyarakat umum. TBM bertujuan menciptakan kebun hortikultura yang terdiri dari kebun buah-buahan, sayuran, bunga dan tanaman hias yang berfungsi sebagai kebun koleksi dan sebagai sumber plasma nutfah, dan diharapkan dapat menjadi taman rekreasi hortikultura yang kelak dapat dikembangkan menjadi pusat studi hortikultura terutama untuk tanaman buahbuahan dan sayuran dataran rendah.

Taman Buah Mekarsari dirancang dengan pola Lamtoro Gung sebagai tema utamanya karena tanaman tersebut merupakan simbol tanaman yang serbaguna, sebagai pelestari lingkungan hidup dan pemenuhan kebutuhan hidup. Keunikan dan manfaat dari Lamtoro Gung ini antara lain: Daun, Bunga dan Buahnya dapat dimanfaatkan untuk pakan ikan, sebagai pakan ternak dapat mempercepat pertumbuhan dan menggemukkan hewan ternak, sebagai tanaman pelindung, tajuknya melindungi tanaman lain dari terik matahari dan hujan, sistem perakarannya yang kuat dapat mencegah erosi dan tanah longsor, sebagai tanaman penghijauan dikota/pedesaan dapat berfungsi mengurangi polusi udara sehingga lingkungannya lebih hijau dan nyaman, tahan terhadap hama dan penyakit tanaman, tahan terhadap genangan singkat, kekeringan, api, dan salinitas, sebagai tanaman pupuk hijau, akarnya dapat menggemburkan dan menyuburkan tanah, mampu 
mengikat zat nitrogen bebas dari udara, dan daun yang gugur membusuk menjadi humus yang menyuburkan tanah, dapat ditanam dilereng-lereng guna mencegah erosi dan longsor.

Hasil wawancara tahap awal, perusahaan memiliki permasalahan yaitu karyawan TBM memiliki masa kerja yang relatif lama, berkisar antara 3-22 tahun namun masa kerja yang cukup lama justru membuat karyawan semakin tidak bersemangat dan cenderung malas-malasan terhadap pekerjaanya dan akhirnya mengakibatkan pekerjaan banyak terlambat. ditambah lagi dengan pendidikan karyawan yang sebagian besar berasal dari lulusan SMA/SMK menjadikan karyawan kurang berkembang dalam melakukan tugas dan berinovasi dalam bekerja. Karyawan telah merasa nyaman di zona pekerjaan mereka, malas-malasan dan tidak ada semangat dalam melakukan pekerjaan ditambah pendidikan yang tidak berkembang membuat karyawan tidak bisa melakukan pekerjaan dengan sempurna. Hal ini sejalan dengan teori motivasi $\mathrm{X}$ McGregor (1960), rata-rata karyawan malas dan tidak suka berkerja, karyawan tidak berambisi mencapai prestasi yang optimal, karyawan lebih suka diawasi dan diperintah dalam melaksanakan tugasnya, dan karyawan lebih mementingkan diri sendiri daripada tujuan perusahaan. Survei di lapangan juga menyatakan hal yang serupa bahwa taman buah mekarsari sangatlah potensial dengan lahan yang luas dan potensipotensi yang berada didalamnya, namun kurang terawatnya lahan-lahan, wahana permainan yang perlu dikembangkan agar bisa bersaing dengan kompetitor.

Berdasarkan latar belakang tersebut, penelitian kinerja karyawan TBM perlu dilakukan untuk dapat menganalisis seberapa besar kompetensi dan motivasi memengaruhi kinerja karyawan dan membuat formulasi strategi untuk meningkatkan kinerja karyawan. Berdasarkan penelitian yang telah dilakukan terlebih dahulu, terdapat penelitian mengenai pengaruh kompetensi dan motivasi terhadap kinerja yang dilakukan secara terpisah maupun bersamaan dan menggunakan berbagai macam teoridanmetodeanalisis. Penelitian ini berbeda dengan penelitian sebelumnya yang dilakukan oleh Riani (2017) mengenai Pengaruh program pelatihan dan motivasi kerja terhadap kinerja karyawan PT TD AUTOMOTIVE COMPRESSOR INDONESIA, dikarenakan penelitian ini menggunakan analisis Structural Equation Modeling (SEM) untuk melihat pengaruh motivasi terhadap kompetensi, pengaruh kompetensi terhadap kinerja dan pengaruh motivasi terhadap kinerja, serta menggunakan metode Analytical hierarchy process (AHP) untuk memperoleh strategi dalam rangka meningkatkan kinerja karyawan di TBM.

Tujuan penelitian ini adalah mengetahui dan menganalisis pengaruh kompetensi karyawan TBM terhadap motivasi karyawan TBM, mengetahui dan menganalisis pengaruh kompetensi terhadap kinerja karyawan TBM, mengetahui dan menganalisis pengaruh motivasi terhadap kinerja karyawan TBM serta merumuskan rekomendasi strategi yang dapat digunakan untuk meningkatkan kinerja karyawan TBM.

\section{METODE PENELITIAN}

Penelitian dilakukan di TBM yang beralamat di Jalan Raya Cileungsi-Jonggol KM.3, Mekarsari, Cileungsi, Bogor, Jawa Barat 16820. Adapun waktu pengambilan data dilakukan sejak bulan Januari sampai dengan Maret 2018. Data yang diperlukan untuk penelitian ini adalah data primer dan data sekunder. Data primer diperoleh dari kuesioner dan wawancara mengenai motivasi, kompetensi dan kinerja karyawan di TBM. Data sekunder diperoleh dari kajian terhadap studi pustaka seperti literatur atau referensi yang berkaitan dengan sumber-sumber lain di luar universitas yang menunjang penelitian. Penelitian ini menggunakan SEM yang digunakan untuk mempelajari hubungan kausalitas antara variabel yang bersifat laten, mampu mengukur secara spesifik kesalahan pengukuran antara variabel laten dengan indikatornya, dan mampu menentukan apakah model yang diajukan yaitu serangkaian hubungan kausalitas antara variabel laten dan hubungan antara variabel laten dengan indikatornya secara simultan dapat diterima atau ditolak. Variabel yang digunakan dalam penelitian ini yaitu kompetensi, motivasi, dan kinerja karyawan. Struktur SEM pada penelitian ini selengkapnya pada Gambar 1.

Untuk mengetahui pengaruh kompetensi dan motivasi terhadap kinerja maka hipotesis dirumuskan sebagai H1: Kompetensi berpengaruh positif dan signifikan terhadap motivasi karyawan, H2: Kompetensi berpengaruh positif dan signifikan terhadap Kinerja karyawan, dan H3: Motivasi berpengaruh positif dan signifikan terhadap kinerja karyawan dengan kerangka pemikiran penelitian selengkapnya pada Gambar 2 . 
Selanjutnya penelitian ini menggunakan AHP dengan menggunakan software Expert Choice 2000. Responden dalam penelitian ini adalah pakar. Pakar merupakan orang yang memiliki kriteria berupa kapabilitas, pengalaman dan memiliki pengaruh dalam kebijakan
(Murniati, 2013). Pakar dalam penelitian ini terdiri dari tujuh orang, yaitu empat dari Pihak Internal TBM dalam hal ini Manager setiap Divisi dan 3 dari pihak eksternal, yaitu pakar SDM dan Agrowisata, dengan struktur hierarki AHP pada Gambar 3.

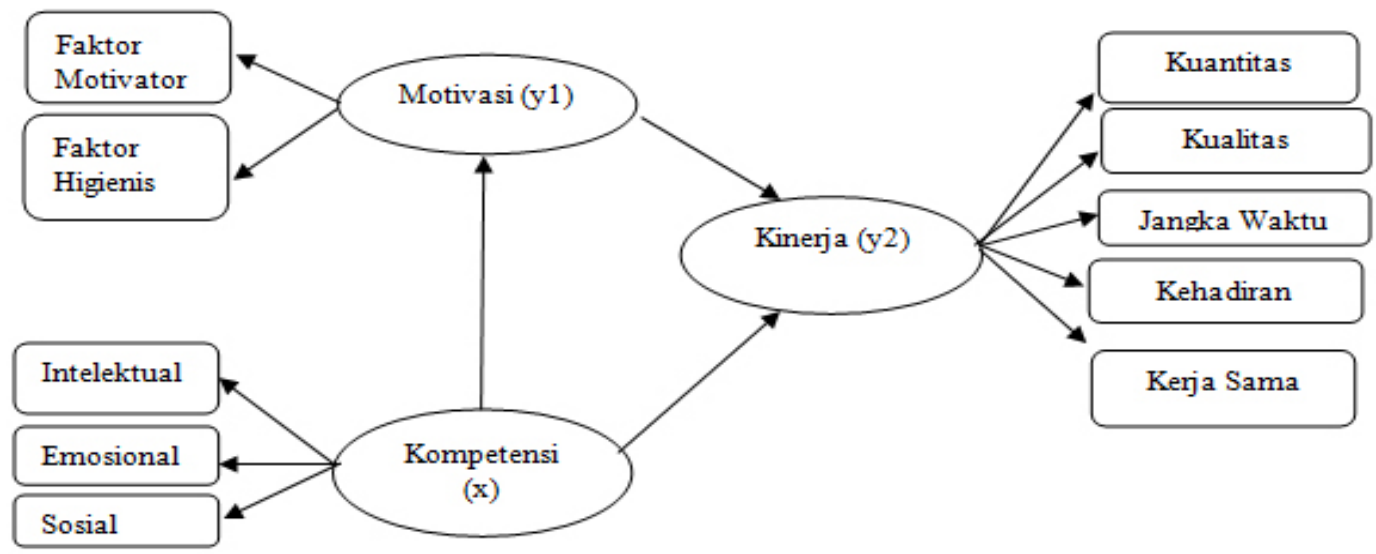

Gambar 1. Struktur SEM

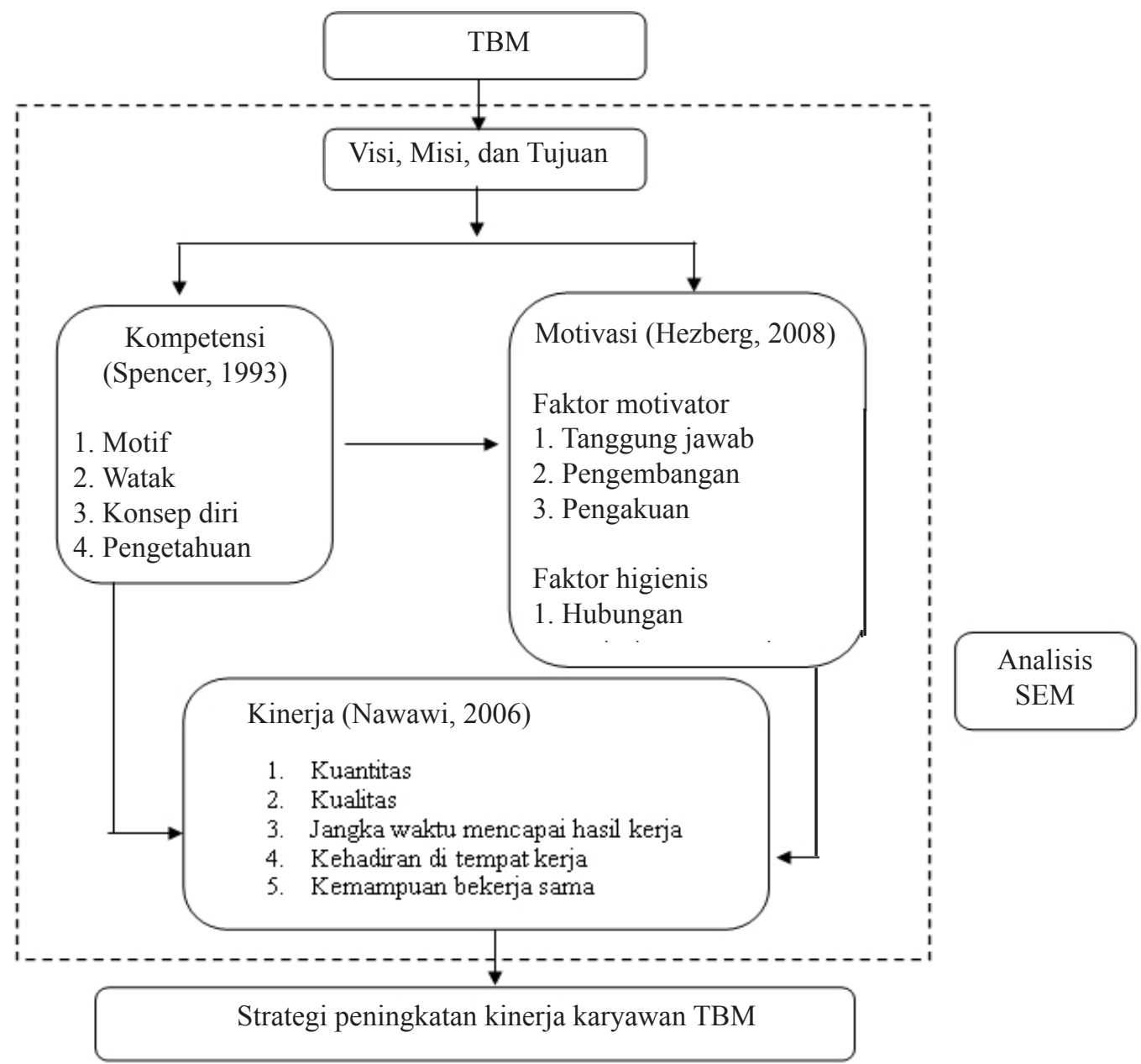

Gambar 2. Kerangka pemikiran penelitian 


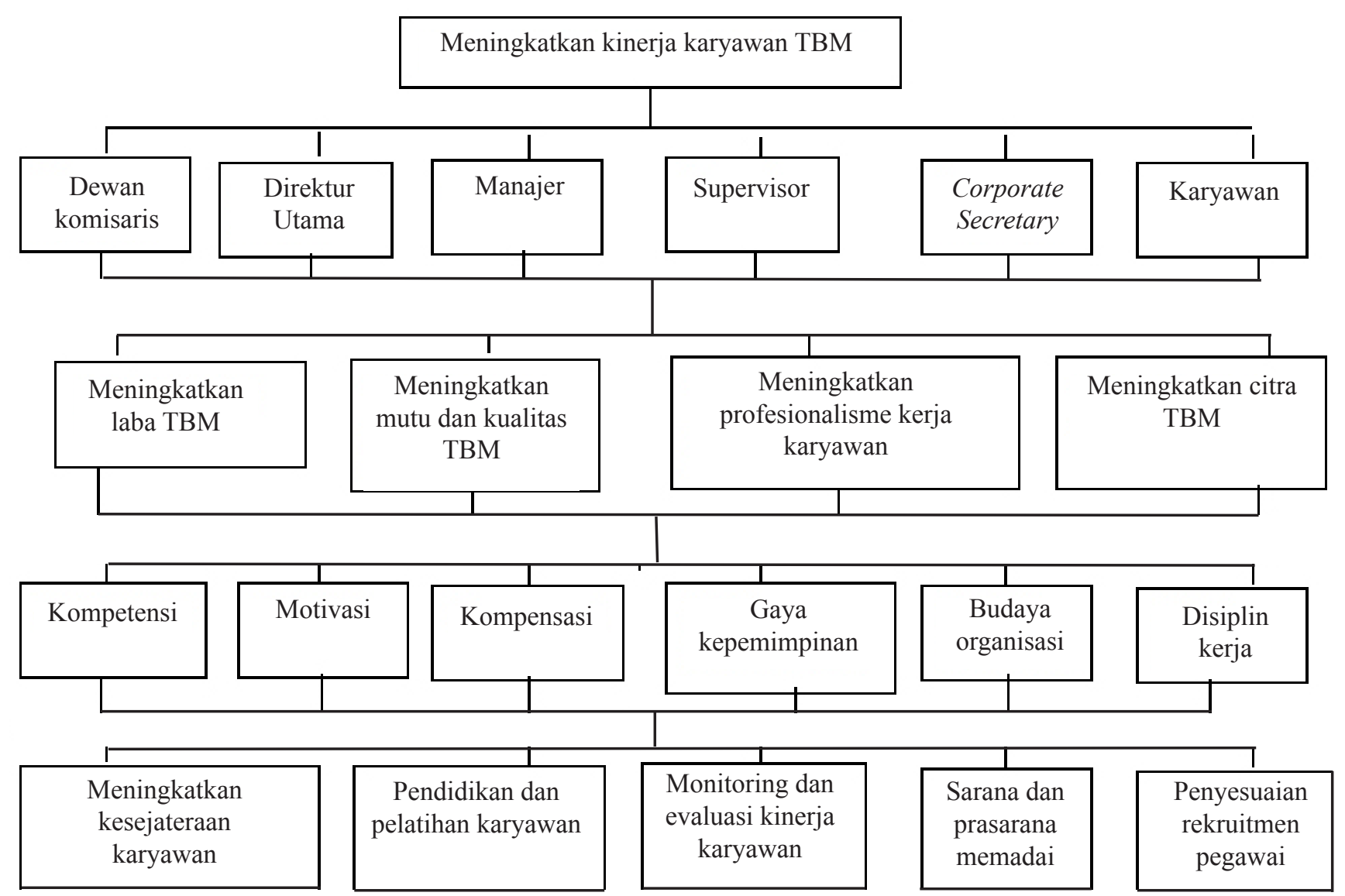

Gambar 3. Struktur Hierarki AHP

\section{HASIL}

\section{Karakteristik Responden}

Gambaran umum karyawan memuat karakteristik responden seperti jenis kelamin, usia, masa kerja, latar belakang pendidikan serta gaji, Berdasarkan hasil olahan data pada Tabel 1, terlihat bahwa jumlah karyawan laki-laki, yaitu $72,46 \%$ dan perempuan sebesar 27,54\%, terlihat dominansi karyawan laki-laki dibandingkan dengan karyawan perempuan karena berdasarkan hasil pengamatan di lapangan memang nampak terlihat di TBM banyak pekerjaan pekerjaan teknis dan di outdoor untuk mengurus tanaman, buah, wisata permainan sedangkan karyawan perempuan banyak ditempatkan di kasir, dan kantor. Sebaran usia responden terbesar yaitu berusia 20-30 tahun dengan presentase sebesar $50,30 \%$ hal ini menunjukkan usia produktif dan diharapkan dapat memberi kontribusi dan pekerjaan terbaik untuk TBM, selanjutnya disusul dengan karyawan yang berusia 30-40 tahun dan 4150 tahun, pada rentang usia kurang dari 20 tahun dan lebih dari 50 tahun berada pada presentase yang sama, yaitu $4,79 \%$, hal ini menunjukkan TBM sebenarnya memiliki karyawan yang banyak pada usia produktif sehingga diharapkan mampu memberikan kontribusi terbaik TBM.

Pada penelitian ini latar belakang pendidikan dibagi menjadi 4 tingkat, yaitu SMA, D3, S1, dan S2, seperti terlihat pada Tabel 1. Latar belakang pendididikan terbesar karyawan TBM yaitu berpendidikan SMA dengan presentase $74,25 \%$, walaupun sebagian besar karyawan TBM yang berpendidikan SMA adalah karyawan yang berada pada bagian kerja lapang namun untuk karyawan yang berada di kantor pun masih cukup banyak yang berada pada tingkat pendidikan SMA, hal ini yang mengindikasikan kurang berkembangnya kompetensi karyawan TBM, hanya 13,17 \% karyawan berpendidikan sarjana, dan $12,57 \%$ berpendidikan diploma, seharusnya semakin tinggi tingkat pendidikan maka cenderung memiliki kompetensi yang tinggi pula dalam bekerja. 
Pada Tabel 1 terlihat juga bahwa masa kerja karyawan sebagian besar telah bekerja kurang dari 5 tahun. Namun, cukup banyak juga yang telah bekerja antara 5-25 tahun hal ini menunjukkan karyawan memiliki loyalitas terhadap TBM, dan penghasilan yang diterima oleh pegawai menunjukkan range hasil yang sesuai. Gaji karyawan terbesar pada tabel berada pada rentang 2-4 juta, hal ini sejalan dengan masa kerja terbesar, yaitu kurang dari 5 tahun.

Berdasarkan nilai-nilai Goodness of Fit, seluruh nilai memenuhi persyaratan kesesuaian model, maka diperoleh kesimpulan bahwa secara umum model memiliki tingkat kecocokan yang baik. Hasil kriteria kesesuaian model dapat dilihat pada Tabel 2.

Pengujian hipotesis bertujuan menjawab rumusan masalah. Pengujian hipotesis yang diajukan dalam penelitian dapat dilihat dari besarnya nilai kritis uji-t statistik. Limitasi untuk menolak dan menerima hipotesis yang diajukan adalah $\pm 1,96$. Pengujian hipotesis penelitian dapat dilihat pada Tabel 3 .

\section{Pengaruh Kompetensi terhadap Motivasi Kerja Karyawan}

Hipotesis pertama pengaruh kompetensi (X) terhadap Motivasi (Y1). Berdasarkan Tabel 3, hasil SEM menunjukkan nilai t hitung sebesar 21,00. Nilai t hitung lebih besar darit tabel sehingga kompetensi berpengaruh positif dan signifikan terhadap motivasi. Hal tersebut sejalan dengan Penelitian yang dilakukan Sudarwati dan Triyanto (2014) menunjukkan bahwa kompetensi berpengaruh positif dan signifikan terhadap motivasi kerja karyawan, hasil ini menunjukkan bahwa dengan memiliki kompetensi didalam menjalankan tugas, maka akan meningkatkan motivasi kerja karyawan. Oleh karena itu, diharapkan jika kompetensi yang dimiliki tinggi maka akan meningkatkan motivasi kerja karyawan. Penelitian yang dilakukan Sihabudin (2013) menunjukkan hasil bahwa kompetensi berpengaruh positif dan signifikan dengan motivasi kerja karyawan.

Tabel 1. Karakteristik responden

\begin{tabular}{llcc}
\hline Karakteristik & & Frekuensi & Persentase (\%) \\
\hline Jenis Kelamin & Laki-laki & 121 & 72,46 \\
& Perempuan & 46 & 27,54 \\
Usia & $<20$ tahun & 8 & 4,79 \\
& $20-30$ tahun & 84 & 50,30 \\
& $31-40$ tahun & 38 & 22,75 \\
& $41-50$ tahun & 29 & 17,37 \\
& $>50$ tahun & 8 & 4,79 \\
Pendidikan & SMA/Sederajat & 124 & 74,25 \\
& DIII & 21 & 12,57 \\
& S1 & 22 & 13,17 \\
Lama Kerja & $<5$ tahun & 80 & 47,90 \\
& $5-10$ tahun & 40 & 23,95 \\
& $11-15$ tahun & 18 & 10,78 \\
& $16-20$ tahun & 9 & 5,39 \\
& $21-25$ tahun & 20 & 11,98 \\
Penghasilan & $26-30$ tahun & 0 & - \\
& $<2$ juta & - & - \\
& $2-4$ juta & 148 & 88,62 \\
& $4-6$ juta & 13 & 7,78 \\
& $>6$ juta & 6 & 3,59 \\
\hline
\end{tabular}


Tabel 2. Hasil kriteria kesesuaian model SEM

\begin{tabular}{lccc}
\hline Goodness of Fit & Cut off Value & Hasil & Keterangan \\
\hline RMR (Root Mean Square Residual) & $\leq 0,05$ atau $\leq 0,1$ & 0,031 & Good fit \\
RMSEA (Root Mean Square Error of Approximation) & $\leq 0,08$ & 0,000 & Good fit \\
GFI (Goodness of Fit) & $\geq 0,9$ & 0,98 & Good fit \\
AGFI (Adjusted Goodness of Fit Index) & $\geq 0,9$ & 0,97 & Good fit \\
CFI (Comarative Fit Index) & $\geq 0,9$ & 1,00 & Good fit \\
NFI (Normed Fit Index) & $\geq 0,9$ & 0,99 & Good fit \\
NNFI (Non-Normed Fit Index) & $\geq 0,9$ & 1,04 & Good fit \\
IFI (Incremental Fit Index) & $\geq 0,9$ & 1,03 & Good fit \\
RFI (Relative Fit Index) & $\geq 0,9$ & 0,99 & Good fit \\
\hline
\end{tabular}

Tabel 3. Pengujian Hipotesis

\begin{tabular}{lcc}
\hline Hipotesis & T Hitung & Keterangan \\
\hline Kompetensi (X) $\rightarrow$ Motivasi (Y1) & 21,00 & Signifikan \\
Kompetensi (X) $\rightarrow$ Kinerja (Y2) & 4,41 & Signifikan \\
Motivasi (Y1) $\rightarrow$ Kinerja (Y2) & 5,02 & Signifikan \\
\hline
\end{tabular}

\section{Pengaruh Kompetensi terhadap Kinerja Karyawan}

Hipotesis kedua pengaruh kompetensi (X) terhadap Kinerja (Y2). Berdasarkan Tabel 3, hasil SEM menunjukkan nilai $t$ hitung sebesar 4,41. Nilai $t$ hitung lebih besar dari $t$ tabel sehingga kompetensi berpengaruh positif dan signifikan terhadap kinerja. Faktor penentu untuk meningkatkan kinerja dapat dilihat dari keseesuaian kompetensi karyawan (Rantesalu et al. 2016). Hasil tersebuh sejalan dengan Permadi (2017) dalam hasil penelitiannya, yaitu kompetensi berpengaruh positif dan signifikan terhadap kinerja karyawan, Sasrahadi (2014) dalam hasil penelitiannya yaitu kompetensi berpengaruh terhadap kinerja karyawan. Kompetensi memiliki hubungan yang erat dengan kinerja, mengacu pada pendapat Spencer dan Spencer (1993) bahwa hubungan antara kompetensi pegawai dan kinerja adalah sangat erat dan penting sekali, relevansinya ada, kuat dan akurat, bahkan ketika seorang pegawai hendak meningkatkan kinerjanya, seharusnya mempunyai kompetensi yang sesuai dengan tugas pekerjaanya. Kompetensi adalah kemampuan dan kemampuan individu untuk tampil lebih baik dalam situasi tertentu (Sita dan Pinapati, 2013). Kompetensi adalah karakteristik orang yang membedakan tingkat kinerja di pekerjaan tertentu(Araujo, 2012). Kompetensi adalah kemampuan seseorang yang dapat terobservasi, yang mencakup pengetahuan, keterampilan dan sikap dalam menyelesaikan suatu pekerjaan atau tugas sesuai dengan standar kinerja yang ditetapkan (Rivai dan Sagala, 2009).

\section{Pengaruh Motivasi terhadap Kinerja Karyawan}

Hipotesis ketiga pengaruh Motivasi (Y1) terhadap Kinerja (Y2). Berdasarkan Tabel 3, hasil SEM menunjukkan nilai t hitung sebesar 5,02. Nilai t hitung lebih besar dari $t$ tabel sehingga motivasi berpengaruh positif dan signifikan terhadap kinerja, artinya jika motivasi semakin baik akan berpengaruh langsung terhadap meningkatnya kinerja karyawan. Motivasi sangat diyakini memiliki pengaruh besar terhadap kinerja karyawan (Gomes dan Cardoso, 2000). Kemampuan dan motivasi harus saling mendukung agar memberikan kinerja yang lebih baik (Mangkunegara, 2005). Motivasi berpengaruh positif dan signifikan terhadap kinerja karyawan (Permadi, 2017), Hasil tersebut sejalan dengan Riani (2017) dalam hasil penelitiannya bahwa motivasi berpengaruh secara positif dan signifikan terhadap kinerja karyawan, Syafei (2016) Kinerja karyawan dipengaruhi oleh budaya organisasi, motivasi, kepemimpinan dan lingkungan. Motivasi akan mendorong seseorang untuk terlibat dalam perilaku tertentu (Achilles et al. 2013). Motivasi memiliki hubungan yang erat dengan kinerja. Motivasi adalah proses manajemen yang memengaruhi prilaku pengetahuan tentang apa yang membuat orang berfikir, berkontribusi pada masyarakat untuk bertindak dan mencapai tujuan spesifik (Rahim, 2013), untuk meningkatkan kinerja dapat dilakukan peningkatan motivasi dari pekerja (Syaifuddin, 2016). Beberapa penelitian menguji hubungan antara motivasi dengan kinerja antara lain Nora (2017) tentang motivasi terhadap kinerja Pegawai Negeri Sipil Kementerian 
Pertanian motivasi intrinsik dan ekstrinsik berpengaruh positif dan signifikan terhadap kinerja, hal ini sejalan dengan penelitian yang dilakukan oleh Salleh et al. (2011) mengenai pengaruh motivasi kerja terhadap kinerja karyawan pada perusahaan pemerintah Malaysia, dengan menggunakan metode regresi berganda. Hasil penelitian menyatakan bahwa variabel motivasi mempunyai pengaruh motivasi yang positif dan signifikan terhadap kinerja karyawan. Dari uraian tersebut dapat ditarik kesimpulan bahwa terdapat indikasi semakin tinggi motivasi karyawan maka akan mempunyai kinerja yang tinggi dalam melaksanakan pekerjaanya.

\section{Analisis AHP}

Analisis selanjutnya, yaitu Analisis AHP dengan menggunakan software Expert Choice (software pendukung yang bersahabat dan memberikan kontribusi besar terhadap keberhasilan metode AHP), karena menggabungkan pengguna grafis secara intuitif, perhitungan prioritas secara otomatis, dan memiliki beberapa cara untuk memproses analisis sensitivitas (Ishizaka dan Labib, 2009).

Analisis unsur aktor terhadap strategi peningkatan kinerja karyawan

Aktor yang paling terlibat dalam peningkatan kinerja karyawan adalah Direktur Utama, dikarenakan tugas dari direktur utama saat ini adalah koordinator, komunikator, pengambil keputusan, pemimpin, pengelola, dan eksekutor dalam menjalankan dan memimpin TBM, memberi arahan dan kebijakan yang menyangkut kelangsungan perusahaan, memutuskan segala sesuatu yang memiliki hubungan langsung dengan aset-aset perusahaan, seperti menjual aset, menerima sponsor, memilih sponsor dan monitoring para manager. Selanjutnya, prioritas kedua, yaitu manager. Manager memiliki peranan penting karena manager yang akan membangun kepercayaan dengan karyawan di setiap divisi, mengembangkan kualitas dari divisinya, mengevaluasi aktivitas karyawan pada divisinya, mengatur dan mengawasi semua hal yang berhubungan dengan kegiatan operasional sehari-hari, memberikan laporan kepada direktur utama tentang kondisi perusahaan, mengambil langkah-langkah teknis dan mengevaluasi masalah yang ada. Prioritas ketiga, yaitu supervisor yang bertugas untuk menjalankan perintah manager di lapangan, bertanggungjawab terhadap anak buah dalam melakukan pekerjaan lapangan. Prioritas keempat yaitu karyawan, prioritas kelima, yaitu corporate secretary dan yang terakhir, yaitu dewan komisaris (Tabel 4).

Analisis unsur tujuan terhadap strategi peningkatan kinerja karyawan

Tujuan yang paling besar yang ingin dicapai dari peningkatan kinerja adalah meningkatkan laba dikarenakan setiap perusahaan menginginkan mencapai laba maksimum untuk perusahaan,diharapkan dengan kinerja karyawan yang baik akan membuat karyawan melakukan pekerjaan meningkat dan membuat daya tarik pengunjung ke TBM meningkat, produksi buah dan pengelolaan tanaman meningkat, selanjutnya tujuan kedua yang ingin dicapai dari peningkatan kinerja karyawan yaitu peningkatan mutu dan kualitas TBM, jika karyawan juga meningkatkan kinerjanya mutu dan kualitas TBM diharapkan akan meningkat, sehingga profesionalisme kerja akan berbanding lurus dengan kinerja yang diberikan dan yang terakhir akan meningkatkan citra TBM. Jika semua telah terpenuhi, yaitu TBM telah memiliki laba yang maksimum, mutu dan kualitas meningkat, profesionalisme kerja meningkat, sehingga akan membuat citra TBM menjadi baik di mata pengunjung, seperti yang terlihat pada Tabel 5.

Tabel 4. Unsur aktor dan bobot prioritas

\begin{tabular}{lcc}
\hline Aktor & Bobot & Prioritas \\
\hline Dewan komisaris & 0,082 & 6 \\
Direktur utama & 0,228 & 1 \\
Manager & 0,220 & 2 \\
Supervisor & 0,210 & 3 \\
Corporate Secretary & 0,122 & 5 \\
Karyawan & 0,137 & 4 \\
\hline
\end{tabular}

Tabel 5. Unsur tujuan dan bobot prioritas

\begin{tabular}{lcc}
\hline Tujuan & Bobot & Prioritas \\
\hline Meningkatkan laba TBM & 0,296 & 1 \\
$\begin{array}{l}\text { Meningkatkan mutu dan kualitas } \\
\text { pelayanan TBM }\end{array}$ & 0,264 & 2 \\
$\begin{array}{l}\text { Meningkatkan profesionalisme kerja } \\
\text { karyawan }\end{array}$ & 0,234 & 3 \\
Meningkatkan Citra TBM & 0,206 & 4 \\
Corporate Secretary & 0,122 & 5 \\
Karyawan & 0,137 & 4 \\
\hline
\end{tabular}


Analisis unsur faktor terhadap strategi peningkatan kinerja karyawan

Faktor yang paling utama memengaruhi karyawan dalam melaksanakan kerjanya, yaitu kompetensi. Hal ini sejalan dengan pendapat Masdar et al. (2009) bahwa kompetensi pegawai memiliki korelasi sangat erat dengan kemampuan mencapai kinerja superior. Selanjutnya prioritas kedua, yaitu motivasi, dilanjutkan dengan kompensasi, gaya kepemimpinan, disiplin kerja dan budaya organisasi, seperti pada Tabel 6 .

Analisis unsur alternatif strategi terhadap strategi peningkatan kinerja karyawan

Alternatif strategi yang paling utama, yaitu meningkatkan kesejahteraan karyawan karena jika pendapatan karyawan bertambah maka diharapkan kesejahteraan akan meningkat, dan diharapkan pula karyawan akan bekerja semakin giat, dan berdampak positif kepada kinerja karyawan. Selanjutnya, mengadakan pendidikan dan pelatihan karyawan penting dilakukan, melihat latar belakang pendidikan karyawan yang sebagian besar masih berada pada tingkat SMA sehingga penting sekali diadakan pendidikan dan pelatihan dari TBM dalam rangka meningkatkan kinerja karyawan. Prioritas yang ketiga, yaitu monitoring dan evaluasi kinerja yang dilakukan dari setiap divisi. Selanjutnya, dibawa pada tingkat atasan, dilanjutkan dengan sarana dan prasaran yang harus memadai agar terciptanya pekerjaan yang memuaskan. Di samping itu, penyesuaian rekruitmen karyawan sehingga karyawan berada pada pekerjaan yang tepat dengan latar belakang pendidikannya dan dengan begitu karyawan bisa merasakan kenyamanan dalam bekerja, tanpa paksaan dan diharapkan dapat meningkatkan kinerja karyawan kepada perusahaan, seperti yang terlihat pada Tabel 7 .

Tabel 6. Unsur faktor dan bobot prioritas

\begin{tabular}{lcc}
\hline Faktor & Bobot & Prioritas \\
\hline Kompetensi & 0,225 & 1 \\
Motivasi & 0,196 & 2 \\
Kompensasi & 0,160 & 3 \\
Gaya Kepemimpinan & 0,142 & 4 \\
Budaya Organisasi & 0,138 & 6 \\
Disiplin Kerja & 0,139 & 5 \\
\hline
\end{tabular}

Tabel 7. Unsur alternatif strategi dan bobot prioritas

\begin{tabular}{lcc}
\hline Alternatif Strategi & Bobot & Prioritas \\
\hline $\begin{array}{l}\text { Meningkatkan kesejahteraan } \\
\text { karyawan }\end{array}$ & 0,295 & 1 \\
Pendidikan dan pelatihan karyawan & 0,208 & 2 \\
Monitoring dan evaluasi kinerja & 0,198 & 3 \\
$\begin{array}{l}\text { Menyediakan sarana dan prasarana } \\
\text { yang memadai }\end{array}$ & 0,160 & 4 \\
$\begin{array}{l}\text { Penyesuaian rekruitmen pegawai } \\
\text { Karyawan }\end{array}$ & 0,139 & 5 \\
\hline
\end{tabular}

\section{Implikasi Manjerial}

Hasil penelitian yang dilakukan mengenai strategi peningkatan kinerja karyawan TBM, prioritas utama adalah faktor kompetensi, sementara itu, aktor yang menjadi peran yang paling berpengaruh terhadap peningkatan kinerja karyawan yaitu direktur utama. Prioritas utama tujuan adalah meningkatkan laba TBM. Meningkatkan kesejahteraan karyawan menjadi alternatif strategi utama dalam rangka peningkatan kinerja karyawan. Kesejahteraan karyawan merupakan bentuk pemberian penghasilan baik dalam bentuk materi maupun dalam bentuk non materi, yang diberikan oleh perusahaan berdasarkan kebijaksanaan perusahaan,dengan tujuan untuk mempertahankandan memperbaiki kondisi fisik dan mental karyawan agar dapat meningkatkan produktifitas (Hasibuan, 2003). Hal ini dirasa penting karena meningkatkan kesejahteraan karyawaan akan membantu karyawan untuk lebih termotivasi dalam bekerja dan akan berimbas pada hasil kerja karyawan yang maksimal.

Kompetensi dan motivasi merupakan dua faktor penting dalam rangka meningkatnya kinerja karyawan TBM. Terkait dengan hal tersebut, pihak manajemen perlu memerhatikan peningkatan kompetensi pegawai, khususnya para karyawan lapang yang memeiliki perang langsung terhadap tanaman, buah dan pengelolaan lahan di Taman Buah.

Manajamen juga perlu meningkatkan motivasi karyawan agar target-target dan tugas-tugas kerja karyawan terpenuhi dan manajemen harus mampu memotivasi karyawan karena merupakan faktor penting untuk menentukan kinerja yang diberikan karyawan kepada perusahaan. Karyawan lapang hendaknya dimotivasi untuk selalu memberikan pekerjaan 
lapang seperti pembibitan, perawatan tanaman dan buah-buahan serta penjagaan wahana permainan, sedangkan karyawan office dimotivasi untuk terus melakukan inovasi dalam bidang wahana permainan yang lebih menarik dalam hal ide agar bisa bersaing dengan kompetitornya, atau penyediaan buah-buah berkualitas. Salah satu motivasi yang bisa dilakukan yaitu memberikan insentif bagi karyawan agar lebih produktif dalam menghasilkan produk-produk unggul di mekarsari. Hal ini sejalan dengan pendapat Saeed dan Shah (2016) yang menyatakan bahwa imbalan dan kompensasi seharusnya diberikan kepada karyawan untuk membuat mereka termotivasi dan berkomitmen.

Manajemen seharusnya memperhatikan faktor-faktor dan alternatif strategi lainnya sesuai dengan skala prioritas yang ada. Gaya kepemimpinan dan disiplin kerja, agak karyawan dan pimpinan memiliki rasa saling percaya, menghormati dan membawa keadaan kerja menjadi nyaman dan lebih termotivasi dalam bekerja, faktor lain yang tidak kalah penting yaitu budaya organisasi, budaya organisasi dapat memberikan sumber motivasi dan komitmen karyawan (Bhatti et al. 2011).

Kepemimpinan merupakan hal penting bagi perusahaan, kepemimpinan berkaitan erat dengan sumber daya manusia (Buble et al. 2014). Kepemimpinan memiliki kaitan yang erat dengan motivasi. Hal ini dikarenakan, keberhasilan seorang pemimpin dalam menggerakkan orang lain dalam mencapai tujuan yang telah ditetapkan sangat bergantung kepada kewibawaan. Di samping itu, pemimpin juga menciptakan motivasi di dalam diri setiap orang bahawan, kolega, maupun atasan pemimpin itu sendiri (Wahjosumidjo, 2002).

\section{KESIMPULAN DAN SARAN}

\section{Kesimpulan}

Hasil dari penelitian ini menunjukkan bahwa kompetensi memengaruhi motivasi karyawan, karena jika karyawan merasa cukup mampu melaksanaan tugasnya dengan kompetensi yang dimilikinya maka akan membuat karyawan termotivasi untuk melakukan pekerjaanya, hasil penelitian menunjukkan bahwa kompetensi memengaruhi kinerja karyawan, Taman Buah dalam hal ini perlu memerhatikan kompetensi yang berada pada diri karyawan karena kompetensi merupakan hal penting untuk peningkatan kinerja karyawan.

Hasil penelitian juga menunjukkan bahwa motivasi memengaruhi kinerja karyawan, karyawan yang memiliki motivasi terhadap pekerjaannya akan menghasilkan pekerjaan yang baik dan memenuhi sasaran yang pada akhirnya akan berdampak pada kinerja yang diberikan kepada perusahaan. Sementara itu, untuk peningkatan kinerja karyawan, aktor yang paling berpengaruh yaitu direktur utama, dikarenakan tugas utama direktur utama di TBM, yaitu memberi arahan dan kebijakan yang menyangkut kelangsungan perusahaan, memutuskan segala sesuatu yang memiliki hubungan langsung dengan aset-aset perusahaan seperti menjual aset, menerima sponsor, memilih sponsor, dan monitoring para manager. Selanjutnya, aktor yang berada pada prioritas kedua yaitu manager, dilanjutkan dengan supervisor, karyawan itu sendiri, coorporate secretary, dan yang terakhir yaitu dewan komisaris.

Alternatif strategi yang dapat dilakukan yaitu meningkatkan kesejahteraan karyawan sebagai prioritas utama dikarenakan jika karyawan telah mencapai kesejahteraan maka akan berdampak pada pekerjaan yang dilakukannya, karyawan menjadi lebih bersemangat dalam menjalankan tugasnya, memiliki motivasi untuk mencapai target-target pekerjaanya dan akan menjadi loyal dengan perusahaan, melakukan pendidikan dan pelatihan bagi karyawan sebagai prioritas kedua, melakukan monitoring dan evaluasi kinerja karyawan, menyediakan sarana dan prasarana yang memadai bagi karyawan dan yang terakhir yaitu penyesuaian rekruitmen pegawai.

\section{Saran}

Taman Buah Mekarsari (TBM) perlu mengadakan pendidikan maupun pelatihan bagi karyawan untuk meningkatkan motivasi dan kompetensi karyawan. Saran penelitian selanjutnya, dapat dibedakan kompetensi karyawan kebun dan karyawan kantor sehingga dapat membuat strategi yang berbeda pula dalam menangani kinerja karyawan. Keterbatasan dalam penelitian ini adalah setelah didapatnya hierarki dan diolah menggunakan software Expert Choice 2000 . 


\section{DAFTAR PUSTAKA}

Achilles WW, Blaskovich J, Pitre TJ. 2013. The relationship between compensation, motivation and earnings management. The Journal of Applied Business Research 29(2): 579-588. https://doi.org/10.19030/jabr.v29i2.7658.

Bhatti WA, Waris S, Zaheer A, Rehman K. 2014. The effect of commitment and motivation on human talent and its contribution to organizational performance. Management and Marketing 6(3): 471-482.

Bubble M, Juras A, Matic I. 2014. Relationship between managers'leadership styles and motivation. Management 19(1): 161-193.

Gomes F, Cardoso. 2000. Manajemen Sumber Daya Manusia. Yogyakarta: Andi Offset.

Hariandja, Marihot TE. 2002. Manajemen Sumber Daya Manusia. Jakarta: Grasindo.

Hasibuan M. 2003. Organisasi dan Motivasi. Jakarta: Bumi Aksara.

Hendriani S, Efni Y, Siswanto N. 2014. Contribution of motivation and competence to the change of organization effectiveness. Journal of applied Sciences 14(22):2994-3000.https://doi. org/10.3923/jas.2014.2994.3000.

Ishizaka A, Labib A. 2009. Analytic Hierarchy Process and Expert Choice: Benefits and Limitations. J-ORInsight 22(4): 201-220. https://doi. org/10.1057/ori.2009.10.

Mangkunegara AP. 2005. Sumber Daya Manusia Perusahaan. Bandung: Remaja Rosdakarya.

Masdar, Asmorowati S, Irianto J. 2009. Manajemen Sumber Daya Manusia Berbasis Kompetensi untuk Pelayanan Publik. Surabaya: Airlangga University Press.

Mathis RL, Jackson JH. 2003. Human Resources Management. Mason: Thomspon

McGregor D. 1960. The Human Side of Enterprise. New York: McGraw-Hill

Nora. 2017. Pengaruh budaya kerja dan motivasi terhadapkinerja pegawainegeri sipil Balitbangtan Kementerian Pertanian [tesis]. Bogor:IPB

Permadi AB. 2017. Pengaruh beban kerja, motivasi, dan kompetensi terhadap kinerja karyawan Bank XYZ [tesis]. Bogor: IPB

Rahim AM. 2013. Rewards and motivation among administrators of universiti sultan zainal abidin (unisza): an empirical study. International Journal of Business and Society 14(2): 265286.
Rantesalu A, Mus RA, Mapparenta, Zaenal A. 2016. The effect of competence, motivation and organizational culture of employee performance. Quest Journals Journal of Research and Business and Management 4(9): 8-14.

Riani EM. 2017. Pengaruh program pelatihan dan motivasi kerja terhadap kinerja karyawan PT TD AUTOMOTIVE COMPRESSOR INDONESIA. Jurnal Aplikasi Manajemen dan Bisnis 3(2):290 298. https://doi.org/10.17358/jabm.3.2.290.

Rivai V, Sagala EJ. 2009. Manajemen Sumber Daya Manusia untuk Perusahaan Dari Teori ke Praktik. Jakarta: PT. RajaGrafindo Persada.

Robbin SP, Judge. 2011. Perilaku Organisasi. Jakarta: Salemba Empat.

Saeed S, Shah FM. 2016. Impact of performance appraisal on employees motivation in Islamic Banking. Arabian Journal of Business and Management Review 5(7): 1-8. https://doi. org/10.12816/0019382.

Salleh F, Dzulkifli Z, Abdullah WAW, Yaakob NHM. 20111. The effect of motivation on job performance of state government employee in Malaysia. International Journal of Humanities and Social Science 1(4):1-8.

Sasrahadi L. 2014. Pengaruh kompetensi, motivasi, dan disiplin kerja terhadap kinerja karyawan di PT INDOPOLY [tesis]. Bogor:IPB.

Sihabudin. 2016. Pengaruh kompetensi dan kompensasi terhadap motivasi kerja di PT Hamatetsu Indonesia. Jurnal Manajemen \& Bisnis Kreatif 1(2): 25-42.

Sita V, Pinapati A. 2013. Competency management as a tool of talent management: a study in Indian IT Organizations. Journal of Economic Development, Management, IT, Finance and Marketing 5(1): 44-56.

Spencer, Spencer. 1993. Competence at Work: Models for Superior Performance. New York: John Wiley \& sons, Inc

Sudarwati, Triyanto A. 2014. Pengaruh kompetensi dan penghargaan terhadap motivasi kerja karyawan PT KAI di Stasiun Sragen. Jurnal Paradigma 12(1): 26-40.

Sulistiyani. 2003. Manajemen Sumberdaya Manusia. Yogyakarta: Graha Ilmu

Sunyoto D. 2015. Manajemen dan Pengembangan Sumber Daya Manusia. Yogyakarta: CAPS.

Sutrisno E. 2009. Manajemen Sumber Daya Manusia. Jakarta: Kencana.

Syafei M. 2016. Faktor-faktor yang memengaruhi 
kinerja karyawan PT PUL Logistik Indonesia. Jurnal Aplikasi Bisnis dan Manajemen 2(3): 217229. https://doi.org/10.17358/JABM.2.3.217.

Syaifuddin. 2016. The influence of work stress and transformational leadership on work motivation and implication of employee's performance (case study). Academy of Strategic Management Journal 15(3): 42-48.

Wahjosumidjo. 2002. Kepemimpinan Kepada Sekolah: Tinjauan Teoritis dan Permasalahannya. Jakarta: PT Raja Grafindo Persada. 